\title{
Административно-территориальные преобразования и переименование населенных пунктов в Калмыкии в 1990-1991 гг.
}

\section{Евгений Александрович Гунаев ${ }^{1}$}

\author{
${ }^{1}$ Калмыцкий научный центр РАН (д. 8, ул. им. И. К. Илишкина, 358000 Элиста, \\ Российская Федерация) \\ кандидат юридических наук, старший научный сотрудник \\ iD 0000-0002-7173-4170. E-mail: gunaevea@kigiran.com \\ (C) КалмНЦ РАН, 2020 \\ (C) Гунаев Е. А., 2020
}

\begin{abstract}
Аннотация. Введение. Период перестройки - время активного реформирования всех сфер советского государства и общества, что нашло отражение и в изменениях административно-территориального устройства страны и ее регионов. Цель данной статьи - на примере Калмыкии исследовать преобразования в административнотерриториальной сфере республики в 1990-1991 гг., обусловленные политической демократизацией в СССР и РСФСР, реабилитацией репрессированных народов, экономическими реформами в период перестройки. Данный процесс исследуется с двух направлений: преобразование рабочих поселков городского типа в сельские поселения и переименование населенных пунктов с возвращением исторических названий. Maтериаль и методы. Использованы официальные (опубликованные и архивные неопубликованные) документы органов государственной власти республики и РСФСР по вопросам административно-территориальных преобразований, данные статистики, научные работы отечественных исследователей по географии населения России и топонимии Калмыкии. Результаты. Рассмотрено административно-территориальное устройство Калмыкии на начало 1990-х гг. в части изменения статуса населенных пунктов такой категории, как рабочие поселки, причины, обусловившие их перевод обратно в сельские поселения. Далее приведены примеры переименования населенных пунктов и образования новых сельских советов в Калмыкии в 1990-1991 гг. Bblвoды. С начала 1990-х гг. в Калмыкии, как и по всей России, начался процесс административной рурализации, который выразился в переводе поселков городского типа в сельские населенные пункты, что было обусловлено социально-экономическими причинами. Еще одним направлением административно-территориальных преобразований явилось активное возвращение исторических наименований ряду населенных пунктов, что объясняется деидеологизацией советского общества, а также этнокультурными факторами.
\end{abstract}

Ключевые слова: Калмыкия, период перестройки, административно-территориальное устройство, преобразование рабочих поселков, переименование населенных пунктов 


\title{
История
}

Благодарность. Исследование проведено в рамках государственной субсидии — проект «Комплексное исследование процессов общественно-политического и культурного развития народов Юга России» (номер госрегистрации: АААА-А19-119011490038-5). Для цитирования: Гунаев Е. А. Административно-территориальные преобразования и переименование населенных пунктов в Калмыкии в 1990-1991 гг. // Монголоведение. 2020. T. 12. № 3. C. 398-413. DOI: 10.22162/2500-1523-2020-3-398-413

UDC 93/94

DOI: $10.22162 / 2500-1523-2020-3-398-413$

\section{Settlements and Localities of Kalmykia: Administrative- Territorial Changes and Renaming, 1990-1991}

\author{
Evgeniy A. Gunaev ${ }^{1}$
}

\author{
${ }^{1}$ Kalmyk Scientific Center of the RAS (8, Ilishkin St., Elista 358000, Russian Federation) \\ Cand. Sc. (Law), Senior Research Associate \\ iD 0000-0002-7173-4170. E-mail: gunaevea@kigiran.com
}

\author{
(C) KalmSC RAS, 2020 \\ (C) Gunaev E. A., 2020
}

\begin{abstract}
Introduction. The period of perestroika was a time of active reform in all spheres of the Soviet state and society, which was reflected in changes in administrative and territorial structures throughout the country and its regions. Goals. The paper examines Kalmykia and provides an insight into administrative-territorial transformations across the republic in 1990-1991 that resulted from political democratization in the USSR and RSFSR, rehabilitation of repressed peoples, and economic reforms of perestroika. This process is studied from two perspectives: transformation of urban-type working settlements into rural ones, and renaming of localities to restore historical names. Materials and Methods. The work analyzes official (published and unpublished archival) documents of regional and federal authorities dealing with administrative and territorial reorganization, statistical data, scientific works of domestic researchers discussing Russia's population geography and toponymy of Kalmykia. Results. The article considers the administrative and territorial structure of Kalmykia in the early 1990s focusing on changes in statuses of 'working' settlements, and reasons underlying their transformation back to 'rural' ones. The paper draws examples of respective processes in Kalmykia during 1990-1991. Conclusions. Since the early 1990s, Kalmykia - like the rest of Russia - initiated administrative ruralization, which manifested itself in transformation of urban-type settlements to rural ones due to socioeconomic reasons. Another trend of administrative -territorial changes was the active restoration of historical names explained by the de-ideologization of Soviet society and ethnocultural factors.

Keywords: Kalmykia, perestroika, administrative-territorial structure, transformation of working settlements, renaming of localities

Acknowledgements: The reported study was funded by government subsidy — project name 'Socio-Political and Cultural Development of South Russia's Peoples: a Comprehensive Research of Respective Processes' (state reg. no. AAAA-A19-119011490038-5).

For citation: Gunaev E.A. Settlements and Localities of Kalmykia: Administrative-Territorial Changes and Renaming, 1990-1991. Mongolian Studies (Elista). 2020. Vol. 12. No. 3. Pp. 398-413. (In Russ.). DOI: 10.22162/2500-1523-2020-3-398-413
\end{abstract}




\section{Введение}

Период перестройки ознаменовался демократизацией советского государства, началом политических и экономических реформ в стране, что отразилось на всех сферах жизни общества. Одним из проявлений данного процесса явилась деидеологизация общества, отказ от коммунистической идеологии, что выразилось в плюрализме общественного мнения, переосмыслении недавнего прошлого страны [Барсенков 2014: 87-88], что также пробудило интерес к историческим корням, к дореволюционной истории, традициям и обычаям предков.

Время перестройки - это также реформирование практически всех сторон жизни общества и государства, включая уровень местного управления. Влияние социально-экономических факторов сказалось и на преобразованиях в административно-территориальной организации социума. В данный период особо выделяются два аспекта преобразований: инициативы о переводе поселков городского типа в состав сельских поселений и переименование населенных пунктов путем возвращения исторических названий.

В статье анализируются официальные (опубликованные и архивные неопубликованные) документы органов государственной власти республики Калмыкия и РСФСР по вопросам административно-территориальных преобразований, данные статистики, научные работы отечественных исследователей по географии населения России и топонимии Калмыкии. Среди архивных документов, помимо собственно постановлений о переименовании населенных пунктов, можно выделить письма в высшие органы государственной власти республики и РСФСР, наглядно демонстрирующие процесс по административно-территориальным преобразованиям в указанный период. Опубликованные документы, сведения в официальных источниках, данные статистики позволяют проследить динамику изменений в данных вопросах. Научные работы по географии населения России показывают, как процессы, происходившие в Калмыкии, находились в общем русле российских преобразований. По вопросу переименования населенных пунктов необходимо привести исторические сведения по топонимии Калмыкии.

Положения о полномочиях органов государственной власти Калмыкии

Вначале рассмотрим конституционные положения о полномочиях органов государственной власти Калмыкии по административно-территориальному устройству.

В Конституции Калмыцкой АССР 1978 г. в редакции от 2 ноября 1989 г. к ведению Верховного Совета республики было отнесено «определение порядка решения вопросов административно-территориального устройства Калмыцкой АССР; решение вопросов об изменении границ районов, городов; образование новых районов и городов, их наименование и переименование» (п. 4, ст. 93) [Закон 1989].

Законом Калмыцкой АССР «Об изменениях Конституции (Основного Закона) Калмыцкой Автономной Советской Социалистической Республики» от 16 августа 1990 г. № 69-IX в главе 7 «Административно-территориальное устройство Калмыцкой АССР» в статье 72 слово «Приозерного», обозначавшее наименование района, было заменено словом «Кетченеровского» [Закон 1990]. 


\section{История}

Законом Калмыцкой Советской Социалистической Республики «Об изменениях и дополнениях Конституции (Основного Закона) Калмыцкой ССР» от 29 января 1991 г. № 116-ІХ «Статья 101. Президиум Верховного Совета Калмыцкой ССР» изложена в новой редакции, в частности было внесено важное дополнение: «Президиум Верховного Совета Калмыцкой ССР вправе в период между сессиями Верховного Совета Калмыцкой ССР с последующим утверждением на очередной сессии Верховного Совета Калмыцкой ССР:

1) производить изменения границ городов и населенных пунктов;

2) упразднять и образовывать сельские и поселковые Советы народных депутатов с учетом мнения населения» [Книга памяти 2004: 386].

Согласно данным статистики на 1 января 1987 г. Калмыцкая АССР состояла из 13 районов, 1 города республиканского подчинения, 2 - районного, 5 поселков городского типа и 99 сельсоветов [СССР 1987: 15]. Поселками городского типа являлись: Комсомольский (1962), Советское (1966), Улан-Хол (1966), Цаган-Аман (1965), Яшкуль (1963) ${ }^{1}$.

Данные населенные пункты были отнесены к категории рабочих поселков, с сохранением за ними прежнего наименования указами Президиума Верховного Совета Калмыцкой АССР соответственно:

- поселок Комсомольский Черноземельского района - 15 мая 1962 г. [Об изменениях 1962: 368].

- поселок Улан-Хол Каспийского района - 7 апреля 1966 г. [Об изменениях 1966а: 590].

- село Советское Приозерного района - 27 августа 1966 г. [Об изменениях 1966б: 904].

- поселок Цаган Аман Юстинского района - 7 декабря 1965 г. [Об изменениях 1965: 736].

- поселок Яшкуль Черноземельского сельского района (в последующем Яшкульского района) - 31 июля 1963 г. [Об изменениях 1963: 1190].

14 ноября 1987 г. Президиум Верховного Совета Калмыцкой АССР своим Указом отнес село Яшалта - административный центр Яшалтинского района - к категории рабочих поселков, сохранив за ним прежнее наименование [Об изменениях 1988: 55].

Итого, согласно сведениям статистики, на 1990 г.: в Калмыцкой АССР было 6 поселков городского типа и 103 сельсовета [Народное хозяйство 1991: 6].

Одним из примеров, свидетельствовавших о начале реформирования статуса ряда населенных пунктов республики, служит письмо Председателя Верховного Совета Калмыцкой ССР - Хальмг Тангч В. М. Басанова Председателю Верховного Совета РСФСР Б. Н. Ельцину. В нем сообщается:

На протяжении двух десятков лет в Калмыкии велось необоснованное преобразование сельских населенных пунктов в рабочие поселки. Как правило, в основе этого были не фактически назревшие изменения образа жизни и экономики, а престижность иметь в составе района и республики рабочие поселки.

Именно таким волюнтаристским путем в июле 1963 г., декабре 1965 г., в августе 1966 г., ноябре 1987 г. села — райцентры соответственно Комсомольский, Яшкуль, Цаган-Аман, Советское (ныне - Кетченеры) и Яшалта были отнесены к категории рабочих поселков. В названных населенных пунктах нет централи-

В скобках приведены годы образования поселков. 
зованного водоснабжения, канализации, асфальта, основная масса населения работает в сельскохозяйственных предприятиях (колхозах, совхозах) и обслуживающей их системе. Ни один населенный пункт не связан непосредственно с железной дорогой, удаленность от г. Элисты колеблется от 100 до 300 км.

Исключением из этого является пос. Комсомольский Черноземельского района, образованный как рабочий поселок в мае 1962 г., когда здесь была Контора глубокого разведочного бурения и основная масса населения, составлявшего 8 тыс. чел., являлась рабочими промышленных предприятий. В настоящее время конторы разведочного бурения в поселке нет, население его сократилось до 4,1 тыс. человек, промышленные предприятия мелкие, и, в основном, их продукция рассчитана на местное потребление. Постоянно возникают трудности с вопросами благоустройства, строительства, торговли и бытового обслуживания.

В условиях активной демократизации и роста общественного самосознания граждан местные советские органы и общественные организации обоснованно требуют преобразования названных рабочих поселков в сельские населенные пункты. В значительной мере эти требования обосновываются заботой Верховного Совета РСФСР о развитии села, отраженной в Постановлении от 1 ноября 1990 г. «О неотложных мерах по улучшению положения женщин, семьи, охраны материнства и детства на селе» и в Законе РСФСР от 21 декабря 1990 г. «О социальном развитии села».

Жители нынешних рабочих поселков Калмыкии справедливо считают, что они необоснованно лишаются льгот, которые предусмотрены названными постановлением и законом. Их мнение поддерживается Верховным Советом Калмыцкой ССР.

Однако решение вопроса о преобразовании пяти рабочих поселков в села осложнено финансовыми проблемами Калмыкии. По расчетам, только на повышение заработной платы на 25 \% специалистам потребуется дополнительно три млн рублей, не считая других затрат, связанных с изменением статуса населенных пунктов.

В свете изложенного просим Вас оказать Калмыцкой ССР помощь в изыскании средств для финансирования преобразования пяти рабочих поселков в сельские населенные пункты.

[Письмо Председателю].

Как видим, в данном письме отсутствует рабочий поселок Улан-Хол, известно, что он был преобразован в сельское поселение чуть позднее, в 1992 г.

Поселки городского типа появились в советский период в 1920-х гг. как своего рода переходная форма между городскими и сельскими поселениями, поскольку разделить все населенные пункты страны строго на города и сельские поселения на тот исторический период не представлялось возможным, «многие городские поселения находились еще на самой начальной стадии своего урбанистического развития» [Симагин 2009: 20]. Поэтому и была введена новая категория «поселки городского типа», не существовавшая до этого ранее нигде в мире.

В конце 1950-х гг. были приняты новые критерии для выделения поселков городского типа. Рабочие поселки должны были отвечать требованиям численности постоянного населения, как правило, не менее 3 тыс. человек, а также не менее 85 \% занятых должны были работать вне сельского хозяйства (Указ Президиума Верховного Совета РСФСР от 12 сентября 1957 г. «О порядке 


\section{История}

отнесения населенных пунктов к категории городов, рабочих и курортных поселков») [Симагин 2009: 21].

Ю. А. Симагин отмечает, что именно начиная с названного периода поселки городского типа оформились как особый промежуточный тип поселений между городом и селом, однако они не находились на пути преобразования в городские поселения в основном по причине недостаточной численности населения. Часть из них (каждый шестой населенный пункт) впоследствии был преобразован обратно в сельское поселение [Симагин 2009: 23].

Согласно Ю. А. Симагину, система расселения России претерпела существенные изменения в 1990-е гг. Процесс сокращения населения в стране особенно ярко проявился именно в поселках городского типа. С сокращением численности населения в поселках городского типа их доля в населении страны также снизилась. Многие поселки городского типа были преобразованы обратно в сельские поселения. Такие преобразования были более характерными для национальных автономий и южных сельскохозяйственных регионов России (Алтайский край, Ростовская, Оренбургская и Тюменская области, республики Карелия, Калмыкия и Алтай). Как правило, этот процесс был характерен для регионов, слабо затронутых урбанизацией, где многие поселки городского типа и раньше фактически являлись сельскими поселениями. В условиях кризиса сократилась занятость в несельскохозяйственных отраслях, а аграрный уклад жизни в них стал превалировать. «В некоторых регионах в сельские поселения были преобразованы все или почти все поселки городского типа, включая райцентры» [Симагин 2009: 24].

Ю. А. Симагин выделяет еще одну причину преобразования поселков городского типа в сельские поселения наряду с депопуляцией и экономическим кризисом. В советский период зачастую по идеологическим соображениям происходило искусственное завышение уровня урбанизации, например, путем неоправданного переведения крупных сельскохозяйственных поселений в городские, что было характерно для южных регионов страны. С ослаблением административного регулирования в 1990-е гг. начался обратный процесс преобразования поселков городского типа в сельские поселения [Симагин 2009: 25].

Население было заинтересованно в преобразовании своих поселений из городских в сельские, поскольку в последних имеются определенные законодательством льготы (предоставление земельного участка для ведения подсобного хозяйства, оплата коммунальных услуг, надбавки к заработной плате и т. д.) [Симагин 2009: 26].

А. С. Чучкалов и А. И. Алексеев приводят сведения о регионах, «где абсолютно все поселки городского типа потеряли свой статус: в европейской части это Чувашия, Липецкая и Оренбургская области и четыре южных республики (Калмыкия, Ингушетия, Кабардино-Балкария и Крым)» [Чучкалов, Алексеев 2019: 19]. Указанные исследователи используют термин «административная рурализация», под которым понимается процесс перевода жителей поселков городского типа в разряд сельского населения. Следствием административной рурализации стало появление определенного роста сельского населения в последующие годы, однако данный рост считается сугубо статистическим, поскольку не учитывается реальное уменьшение сельского населения [Чучкалов, Алексеев 2019: 32-33]. 
Рассмотрим далее примеры переименования населенных пунктов и образования новых сельских советов в Калмыкии в 1990-1991 гг.

18 октября 1990 г. в Яшалтинском районе был образован Краснопартизанский сельсовет с административным центром в селе Красный партизан. В состав Краснопартизанского сельского Совета было включено село Красный партизан с исключением его из административного подчинения Соленовского сельского Совета народных депутатов. Президиуму Яшалтинского районного Совета народных депутатов поручалось провести выборы в Краснопартизанский сельский совет народных депутатов в соответствии с Законом Калмыцкой ССР о выборах народных депутатов местных Советов народных депутатов Калмыцкой ССР [Постановление 1990г].

Красный партизан - поселок Яшалтинского района, административный центр сельского поселения. В 1920-е гг. здесь возникла коммуна «Красный партизан», которая стала основой будущего поселения с таким же названием. В 1930-е гг. был создан сельсовет. В 1942-1943 гг. он в течение полугода был оккупирован фашистами. 28 декабря 1943 г. Калмыцкая АССР была ликвидирована, а калмыцкий народ подвергся насильственному переселению. Поселок Красный партизан в связи с ликвидацией республики был передан в Ростовскую область. С восстановлением автономии в 1957 г. поселок был возвращен в состав Калмыкии. Здесь был организован мясосовхоз «Яшалтинский». 18 октября 1990 г. был вновь создан сельский совет [Кичикова, Манджиева, Супрун 2017: 119].

В октябре 1990 г. поселку Прудовый было возвращено прежнее историческое наименование Найнтахн, и Прудовскому сельскому Совету народных депутатов Целинного района — наименование Найнтахинский [Постановление 1990б].

Считается, что уже в 1835 г. калмыки рода найнтахинов занялись хлебопашеством, в 1904 г. в хотоне насчитывалось 437 кибиток. В 1928 г. поселок получил название Сямрнг, а через два года - Кючн Ниицян, вероятно, в честь названия местного колхоза. В декабре 1943 г., после того как калмыки были насильственно переселены, территория была передана в Астраханскую область, и здесь был организован совхоз «Прудовый», по имени которого с 1944 г. стал называться и поселок. В 1990 г. поселку было возвращено историческое наименование, данное по названию древнего калмыцкого рода [Кичикова, Манджиева, Супрун 2017: 139].

Селу Полынное было возвращено прежнее историческое наименование Бергин, и Полыненскому сельскому Совету народных депутатов Юстинского района - Бергинский [Постановление 1990в].

Бергин - село в Юстинском районе, весной 1924 г. здесь работала Поволжская колонизационно-мелиоративная экспедиция, которая подыскивала пригодные места для перевода кочевого населения на оседлый образ жизни. В 1927 г. было основано село Гурвн Улан Актюбинского аймака Хошеутовского улуса, которое через год стало называться Бергин, в созданный здесь сельсовет входило 7 хотонов. В октябре 1929 г. был образован колхоз, один из первых в республике. Поначалу он носил имя тогдашнего ответственного секретаря Калмыцкого обкома партии Х. М. Джалыкова, затем, после того как Хохола Манджиевича сняли с должности, колхозу было присвоено имя советского партийного и государственного деятеля С. М. Кирова. После насильственного 


\section{История}

переселения калмыков в январе 1944 г. село было передано в Астраханскую область. В 1946 г. здесь организуется новый каракулеводческий совхоз «Полынный», по имени которого село получает новое название. 18 октября 1990 г. ему было возвращено исконное наименование Бергин, которое образовано от калмыцкого слова бергн 'старшая невестка, жена старшего брата, сноха' [Кичикова, Манджиева, Супрун 2017: 52-53].

Поселку Красносельск было возвращено прежнее историческое наименование Ики-Бухус, и Красносельскому сельскому Совету народных депутатов Малодербетовского района — название Ики-Бухусовский [Постановление 1990а].

Название Ики-Бухус происходит от древнего калмыцкого рода бухусов, который еще в XIX в. разделился на две части: ики-бухусов и бага-бухусов. К концу 1869 г. в Ики-Бухусовском аймаке насчитывалось 228 кибиток, в Бага-Бухусовском - 64. В начале XX в. появился оседлый поселок, который получил название Красное Село. Рядом находились Бага-Бухусовский и Ики-Бухусовский поселки, в каждом из них были сельсоветы. В результате насильственного переселения калмыков в декабре 1943 г. эти калмыцкие поселки прекратили свое существование, а их территория была передана Сталинградской области. 10 января 1950 г. был создан овцеводческий совхоз № 2, на его центральной усадьбе образован Красносельский поселковый совет. Позже совхоз стал называться «Красносельский».

После возвращения из депортации калмыки стали селиться в Красном Селе. В начале 1990-х гг. поселку возвращено прежнее название Ики-Бухус [Кичикова, Манджиева, Супрун 2017: 100-101].

Постановлением Верховного Совета Калмыцкой ССР - Хальмг Тангч «О возвращении г. Каспийский Калмыцкой ССР прежнего исторического наименования Лагань» от 22 января 1991 г. Верховный Совет Калмыцкой ССР постановил возвратить г. Каспийскому прежнее историческое наименование Лагань [Постановление 1991а].

М. У. Монраев и П. Д. Сангаджиев, рассматривая различные исторические версии о происхождении названия Лагань, приводят одну из них, что поселок свое название получил от имени калмыка Лаг, который якобы пас скот на этом острове. Отмечая, что калмыки багутовского рода еще до основания поселка действительно кочевали на этом и соседних островах, они пришли к выводу, что данное предположение неверно. Калмыки часто нарекали новорожденных по названию местности, урочища. «Поэтому более вероятно, свое имя Лаг получил от названия острова, а не наоборот» [Монраев, Сангаджиев 1981: 72].

По мнению М. У. Монраева и П. Д. Сангаджиева, название поселка Лагань происходит от названия острова, на котором основался одноименный рыбацкий поселок. «В топонимии известны случаи, когда многие города, села и другие географические объекты вошли в историю по названию той местности, гор, рек, озер, на которых они основывались. Что касается названия острова Лагань, то, как полагают старожилы, оно возникло, видимо, от характера почвы морского побережья, по преимуществу песчаной, топкой, лагунной. Морские волны постоянно намывают вдоль побережья, особенно в заводях, песчаные дюны, за которыми задерживается вода в период спада, образуя старицы, топкие мелководные лагуны. Такие места по-калмыцки называют „ла“, что значит трясина, 
болото, ил» [Монраев, Сангаджиев 1981: 73]. «Топоним Лагань воспринимается как типично калмыцкий и без каких-либо затруднений и натяжек может быть отнесен к системе калмыцкого словообразования, т. е. лаг - корневая морфема со значением „ил, илистыйее , ан - суффикс принадлежности родительного падежа, а появление мягкого знака в финале связано, видимо, с передачей этого топонима на русский язык, так как Лагань произносится в калмыцком языке с твердым конечным - н» [Монраев, Сангаджиев 1981: 73-74].

Поселок Лагань основан в 1870 г. самовольными поселенцами-крестьянами из центральных губерний. В 1936 г. он преобразован в рабочий поселок, а в 1944 г. в рабочий поселок Каспийский, который в 1963 г. стал городом районного подчинения [Монраев, Сангаджиев 1981: 74-77].

21 февраля 1991 г. Верховный Совет Калмыцкой ССР постановил возвратить поселку Октябрьский прежнее историческое наименование Хошеут и Джиргилтинскому сельскому Совету народных депутатов Октябрьского района название Хошеутовский [Постановление 1991б].

Поселок возник в начале XX в., первоначально назывался село Канава. 25 ноября 1920 г. вместе с Икицохуровским улусом вошел в состав Калмыцкой автономной области. С 1938 г. входил в Кетченеровский улус. 28 декабря 1943 г. калмыки были насильственно депортированы, а республика - ликвидирована, и село включили в Астраханскую область, где его переименовали в поселок Октябрьский. В 1957 г. он был возвращен в состав Калмыкии. В 1961 г. поселок включен в совхоз «Сарпа», в 1977 г. - во вновь созданный Октябрьский район (райцентр - Большой Царын). В 1983 г. был создан совхоз «Октябрьский». В 1991 г. поселок был переименован в Хошеут [Кичикова, Манджиева, Супрун 2017: 204-205].

7 июня 1991 г. поселку Партизанский Малодербетовского района было возвращено прежнее историческое наименование Унгун Терячи [Постановление 1991в].

Согласно объяснительной записке Отдела по вопросам работы Советов народных депутатов Секретариата Верховного Совета Калмыцкой ССР - Хальмг Тангч о возвращении поселку Партизанский Малодербетовского района прежнего исторического наименования Унгун Терячи, место, на котором сейчас располагается поселок, в начале 1860-х гг. комплексной Кумо-Манычской экспедицией было определено под небольшое оседлое поселение, в шесть хуторов, у озера Унгун Терячи, название которого означает «затерявшийся жеребенок».

Для обживания этого места экспедицией И. И. Жилинского была построена водосборная плотина. Возникшее у этого гидротехнического сооружения поселение калмыков входило в Центральный аймак Малодербетовского улуса. В начале 1920-х гг. оно явилось центром Унгунтерячинского сельского Совета той же территориально-административной единицы Калмыкии.

В 1930-х гг. Унгун Терячи входило в Малодербетовский сельский Совет. С передачей в 1944 г. Малодербетовского улуса в состав Сталинградской области поселение с таким названием теряется. Позже на картах Калмыкии оно появляется под наименованием «Партизанский». Существенных аргументов в этом переименовании не вскрыто. 


\section{История}

На начало 1990-х гг. на территории Чапаевского сельского Совета, куда входил поселок Партизанский, проживало 454 человека, в том числе калмыцкой национальности - 441. Жители постоянно поднимали данный вопрос на собраниях, сходах с тем, чтобы поселку возвратили прежнее наименование Унгун Терячи. С аналогичной повесткой была проведена сессия Чапаевского сельского Совета народных депутатов, на которой депутаты поддержали предложение о возвращении исторического наименования [Постановление 1991в].

27 августа 1991 г. поселку Партизанский Кетченеровского района было возвращено прежнее историческое наименование Гашун-Бургуста и Партизанскому сельскому Совету народных депутатов Кетченеровского района - Гашун-Бургустинский [Постановление 1991г].

Согласно объяснительной записке Отдела по вопросам работы Советов народных депутатов Секретариата Верховного Совета Калмыцкой ССР Хальмг Тангч о возвращении поселку Партизанский прежнего исторического наименования Гашун-Бургуста и Партизанскому сельскому Совету народных депутатов Кетченеровского района - Гашун-Бургустинский, жители поселка Партизанский обратились в Партизанский сельский Совет народных депутатов с просьбой возвратить населенному пункту прежнее историческое наименование Гашун-Бургуста, а Партизанский сельский Совет переименовать в Гашун-Бургустинский.

Поселок находится в балке Гашун-Бургуста, где протекает одноименная речка. Поселок основан в 1965 г. на базе четвертой фермы племзавода «Сухотинский».

На территории Партизанского сельского Совета народных депутатов проживало на тот период 1030 чел., из них калмыцкой национальности 85 \%. Жители постоянно поднимали данный вопрос на собраниях, сходах с тем, чтобы поселку возвратили прежнее наименование Гашун-Бургуста. С аналогичной повесткой была проведена сессия Партизанского сельского Совета народных депутатов, на которой депутаты поддержали предложение о переименовании сельского Совета народных депутатов в Гашун-Бургустинский [Постановление 1991г].

Согласно указу Президиума Верховного Совета Калмыцкой ССР - Хальмг Тангч от 27 августа 1991 г. был образован Сарульский сельсовет в Черноземельском районе с административным центром в поселке Сарул за счет части Адыковского сельского совета [Указ 1991].

Поселок Сарул возник по инициативе 1-го секретаря Калмыцкого обкома КПСС Героя Советского Союза Б. Б. Городовикова, который предложил создать на бывшей ферме самостоятельный совхоз «Восточный». В 1970-е гг. началось строительство жилья и производственных помещений, в 1977 г. поселок получил современное название от калмыцкого слова сарул 'светлый, ясный'. В 1991 г. в Саруле был создан самостоятельный сельский совет [Кичикова, Манджиева, Супрун 2017: 170-171].

При переименовании населенных пунктов и возвращении исторических названий важное значение имело мнение межведомственной комиссии по географическим названиям. Приведем письмо Постоянной межведомственной комиссии по географическим названиям Главного управления геодезии и картографии при Совете Министров СССР в Отдел по работе Советов Верховного 
Совета Калмыцкой ССР от 25 сентября 1991 г., свидетельствующее о принципах присвоения национальных названий.

В данную комиссию поступили на заключение постановления Верховного Совета Калмыцкой ССР о возвращении исторических наименований некоторым населенным пунктам. В письме сказано следующее:

Уважая волю калмыцкого народа, считаем возможным обратить ваше внимание на необходимость уточнения русской формы некоторых названий с тем, чтобы они более точно соответствовали произношению на калмыцком языке и существующим правилам написания на русском языке.

1) поселок Южный: решением № 28 Цаган-Нурского сельского Совета народных депутатов Октябрьского района предлагается вернуть название Босхач, а в постановлении Верховного Совета Калмыцкой АССР от 16 августа 1990 г. значится название Босхачи. Национальная форма - Босхач (здесь и далее калмыцкая форма названий определяется по списку основных географических названий Калмыцкой АССР, содержащемуся в Калмыцко-русском словаре 1977 г., изд.). По нашему мнению, произношению названия более соответствует форма Босхачи, поэтому рекомендуем принять эту форму.

2) поселок Прудовый: постановлением Верховного Совета Калмыцкой АССР от 18 октября 1990 г. возвращается название Найнтахн и Прудовскому сельскому совету — Найнтахинский, хотя решением № 57 от 25 сентября Прудовского сельского Совета предлагалось принять название - Найнтахин и сельскому Совету - Найнтахиновский. Еще один вариант предлагаемого названия значится в постановлении № 20 Целинного района — поселок Наинтхн и сельский Совет - Наинтахиновский. Национальная форма - Найнтахн, поддерживаем решение сельсовета о названиях Найнтахин и Найнтахиновский.

3) поселок Октябрьский: предлагаемое название Хошеут. Название родовой группы, по которой получил наименование населенный пункт, в различных источниках писалось по-разному: хошуты, хошеуты, хошоуты и др. Калмыцко-русский словарь даёт калмыцкую форму хошуд и ее перевод на русский язык - хошуты, поэтому, возвращая историческое название, следовало бы согласовать его с современным произношением названия этнической группы, т. е. Хошут, если только это не расходится с произношением данного географического названия местным населением.

4) районный поселок Советское: предлагается вернуть название Кетченеры. Национальная форма - Көчнр. Заметим, что звуку, обозначаемому в калмыцком языке буквой «ө» в середине слова, в русском языке более соответствует «ё». Поэтому, если это не противоречит произношению названия местными жителями, рекомендуем форму Кётченеры и района — Кётченеровский.

5) поселок Мирный — предлагается Лиджин Худук, поселок Партизанский — Унгун Терячи, поселок Красносельск - Ики-Бухус.

Названия, состоящие из двух или более слов, в передаче по-русски традиционно пишутся через дефис, как предлагается вами в последнем случае, т. е. Лиджин-Худук, Унгун-Тёрячи (здесь также применяется передача буквы «ө» через «ё»).

6) поселок Озерный - возвращается название Чарлакта (национальная форма - Чәрләкт), хотя в названиях других населенных пунктов, например, в предлагаемом вами Унгун Терячи (национальная форма - Үнһн Төөрәч) или в существующем Амтя-Уста (Әмтә Уста) буква «ә» передается после согласного звука на русский язык как «я». По нашему мнению, форма Чярлякта более точно соответствует сложившейся практике передачи на русский язык. 


\section{История}

Свое окончательное заключение по предлагаемым названиям Комиссия сможет дать только после вашего ответа.

Одновременно следует отметить, что не только во вновь предлагаемых названиях, но и в справочниках административно-территориального деления в других изданиях (в частности, в картографических) одни и те же явления калмыцкого языка отражаются неоднозначно. Так, в ряде случаев редуцированные гласные калмыцкого языка «проявляются» в передаче по-русски, а иногда нет (ср. Босхач - Босхачи, Найнтахн - Найнтахин и т. д.). Неоднозначно также передаются буквы «ө», «ә» и др.

Многие из поставленных в письме вопросов возникают потому, что не существует научного списка или словаря калмыцких географических названий и нет еще стабильной системы передачи калмыцких топонимов на русский язык.

Думается, что совместными усилиями вашей Республики и нашей Комиссии можно было бы начать работу над созданием и словаря, и правил. Хотелось бы узнать ваше мнение по этому вопросу.

Председатель Комиссии А. С. Земцов.

[Письмо 1991].

Как видим, при переименовании возникали вопросы чисто технического характера в части написания наименований объектов на русском языке. Никаких политических и других ограничений не наблюдалось.

\section{Выводы}

С начала 1990-х гг. в Калмыкии, как и по всей России, начался процесс административной рурализации, который выразился в переводе поселков городского типа в сельские населенные пункты, что было обусловлено социально-экономическими причинами (закрытием промышленных предприятий вследствие экономического кризиса и, соответственно, ростом сельскохозяйственной занятости населения).

Еще одним аспектом административно-территориальных преобразований явилось активное возвращение исторических наименований ряду населенных пунктов, что объясняется деидеологизацией советского общества, а также этнокультурными факторами. Инициатива переименования исходила от самих жителей, учитывался национальный состав населения.

\section{Источники}

Закон 1989 - Закон Калмыцкой АССР «Об изменениях и дополнениях Конституции (Основного Закона) Калмыцкой АССР» от 2 ноября 1989 г. // Советская Калмыкия. 1989. 15 ноября. С. $1-2$.

Закон 1990 - Закон Калмыцкой АССР «Об изменениях Конституции (Основного Закона) Калмыцкой Автономной Советской Социалистической Республики» от 16 августа 1990 г. № 69-ІХ // НА РК. Ф. Р-1. Оп. 4. Д. 2996. Л. 17-18.

Об изменениях 1962 - Об изменениях в административно-территориальном делении РСФСР // Ведомости Верховного Совета РСФСР. М.: Издание Верховного Совета РСФСР, 1962. № 23 (14 июня). 368 с.

Об изменениях 1963 - Об изменениях в административно-территориальном делении РСФСР // Ведомости Верховного Совета РСФСР. М.: Издание Верховного Совета РСФСР, 1963. № 35 (5 сентября). 736 с. 
Об изменениях 1965 - Об изменениях в административно-территориальном делении РСФСР // Ведомости Верховного Совета РСФСР. М.: Издание Верховного Совета РСФСР, 1965. № 52 (30 декабря). 1228 с.

Об изменениях 1966а - Об изменениях в административно-территориальном делении РСФСР // Ведомости Верховного Совета РСФСР. М.: Издание Верховного Совета РСФСР, 1966. № 28 (14 июля). 592 с.

Об изменениях 1966 - Об изменениях в административно-территориальном делении РСФСР // Ведомости Верховного Совета РСФСР. М.: Издание Верховного Совета РСФСР, 1966. № 41 (13 октября). 904 с.

Об изменениях 1988 - Об изменениях в административно-территориальном делении РСФСР // Ведомости Верховного Совета РСФСР. М.: Издание Верховного Совета РСФСР, 1988. № 3 (21 января). 56 с.

Письмо 1991 - Письмо Постоянной межведомственной комиссии по географическим названиям Главного управления геодезии и картографии при Совете Министров СССР в Отдел по работе Советов Верховного Совета Калмыцкой ССР от 25 сентября 1991 г. // НА РК. Ф. Р-1. Оп. 4. Д. 2543. Л. 13-15.

Письмо Председателю - Письмо Председателю Верховного Совета РСФСР Ельцину Б. Н. (без даты, не ранее 15.11.1990) // НА РК. Ф. Р-1. Оп. 4. Д. 2541. Л. 18-19.

Постановление 1991 - Постановление Верховного Совета Калмыцкой ССР - Хальмг Тангч «О возвращении городу Каспийский Калмыцкой ССР прежнего исторического наименования Лагань» от 22 января 1991 г. № 108-IX // НА РК. Ф. Р-1. Оп. 4. Д. 3031 . Л. 24.

Постановление 19916 - Постановление Верховного Совета Калмыцкой ССР - Хальмг Тангч «О возвращении поселку Октябрьский прежнего исторического наименования Хошеут и Джиргилтинскому сельскому Совету народных депутатов Октябрьского района — Хошеутовский» от 21 февраля 1991 г. № 167-IX // НА РК. Ф Р.-1. Оп. 4. Д. 3033. Л. 158.

Постановление 1991в - Постановление Президиума Верховного Совета Калмыцкой ССР - Хальмг Тангч «О возвращении поселку Партизанский Малодербетовского района прежнего исторического наименования Унгун Терячи» от 7 июня 1991 г. № 246П-ІХ // НА РК. Ф. Р-1. Оп. 4. Д. 3015. Л. 46-47.

Постановление 1991г - Постановление Президиума Верховного Совета Калмыцкой $\mathrm{CCP}$ - Хальмг Тангч «О возвращении поселку Партизанский прежнего исторического наименования Гашун-Бургуста и Партизанскому сельскому Совету народных депутатов Кетченеровского района - Гашун-Бургустинский» от 27 августа 1991 г. № 279П-ІХ // НА РК. Ф. Р-1. ОП. 4. Д. 3014. Л. 140-141.

Постановление 1990а - Постановление Верховного Совета Калмыцкой ССР «О возвращении поселку Красносельск прежнего исторического наименования Ики-Бухус и Красносельскому сельскому Совету народных депутатов Малодербетовского района - Ики-Бухусовский» от 18 октября 1990 г. № 100-ІХ // НА РК. Ф. Р-1. Оп. 4. Д. 2998. Л. 92.

Постановление $1990 б$ - Постановление Верховного Совета Калмыцкой ССР «О возвращении поселку Прудовый прежнего исторического наименования Найнтахн и Прудовскому сельскому Совету народных депутатов Целинного района - Найнтахинский» от 18 октября 1990 г. № 98-ІХ // НА РК. Ф. Р-1. Оп. 4. Д. 2998. Л. 90.

Постановление 1990в - Постановление Верховного Совета Калмыцкой ССР «О возвращении селу Полынное прежнего исторического наименования Бергин и Полыненскому сельскому Совету народных депутатов Юстинского района - Бергинский» от 18 октября 1990 г. № 99-ІХ // НА РК. Ф. Р-1. Оп. 4. Д. 2998. Л. 91. 


\section{История}

Постановление 1990г - Постановление Верховного Совета Калмыцкой ССР «Об образовании Краснопартизанского сельсовета в Яшалтинском районе» от 18 октября 1990 г. № 97-IX // НА РК. Ф. Р-1. Оп. 4. Д. 2998 Л. 89.

Указ 1991 - Указ Президиума Верховного Совета Калмыцкой ССР - Хальмг Тангч «Об образовании Сарульского сельсовета в Черноземельском районе» от 27 августа 1991 г. № 281П-ІХ // НА РК. Ф Р-1. ОП. 4. Д. 3015. Л. 49.

\section{Литература}

Барсенков 2014 - Барсенков А. С. Политика перестройки и реформирование советского общества в 1985-1991 гг. // Российская история. 2014. № 6. С. 77-98.

Кичикова, Манджиева, Супрун 2017 - Кичикова Н. А., Манджиева Э. Б., Супрун В. И. Топонимический словарь Республики Калмыкия. Элиста: НПП «Джангар», 2017. $272 \mathrm{c}$.

Книга памяти 2004 - Книга памяти ссылки калмыцкого народа. Т. 1. Кн. 3: Восстановление автономии и реабилитация калмыцкого народа. В 2-х ч. Ч. 2. Реабилитация калмыцкого народа (1964-2003 гг.): сб. док-тов и мат-лов. Элиста: Калм. кн. изд-во, 2004. $684 \mathrm{c}$.

Монраев, Сангаджиев 1981 - Монраев М. У., Сангаджиев П. Д. О возникновении поселка Лагань и происхождении его названия // Исследования по исторической географии Калмыцкой АССР. Элиста: КНИИИФЭ, 1981. С. 72-78.

Народное хозяйство 1991 - Народное хозяйство РСФСР в 1990 г.: Стат. ежегодник / Госкомстат РСФСР. М.: Республиканский информационно-издательский центр, $1991.592 \mathrm{c}$.

Симагин 2009 - Симагин Ю. А. Изменение роли поселков городского типа в системе расселения России на протяжении XX века // Вестник Московского городского педагогического университета. Серия: Естественные науки. 2009. № 1. С. 20-27.

СССР 1987 - СССР. Административно-территориальное деление союзных республик: на 1-е января 1987 года: [справочник] / Президиум Верховного Совета СССР; [сост. В. А. Дударев, Н. А. Евсеева]. М.: Известия, 1987. 670 с.

Чучкалов, Алексеев 2019 - Чучкалов А. С., Алексеев А. И. «Новые» сельские населенные пункты - бывшие поселки городского типа // Известия Российской академии наук. Серия географическая. 2019. № 6. С. 18-34.

\section{Sources}

Decree of the Supreme Soviet of the Kalmyk ASSR - Khalmg Tangch 'On Historical Renaming of Kaspiysky back to Lagan' of 22 January 1991 No. 108-IX. At: National Archive of the Republic of Kalmykia. Coll. P-1. Cat. 4. File 3031. P. 24. (In Russ.)

Decree of the Supreme Soviet of the Kalmyk ASSR - Khalmg Tangch 'On Historical Renaming of Oktyabrsky back to Khosheut, and Dzhirgiltinsky Rural Soviet of People's Deputies (Oktyabrsky District) back to Khosheutovsky One' of 21 February 1991 No. 167-IX. At: National Archive of the Republic of Kalmykia. Coll. P-1. Cat. 4. File 3033. P. 158. (In Russ.)

Decree of the Supreme Soviet of the Kalmyk ASSR - Khalmg Tangch 'On Historical Renaming of Partizansky (Maloderbetovsky District) back to Ungun Teryachi' of 7 June 1991 No. 246P-IX. At: National Archive of the Republic of Kalmykia. Coll. P-1. Cat. 4. File 3015. Pp. 46-47. (In Russ.)

Decree of the Supreme Soviet of the Kalmyk ASSR - Khalmg Tangch 'On Historical Renaming of Partizansky (Ketchenerovsky District) back to Gashun-Burgusta, and Partizansky Rural Soviet of People's Deputies to Gashun-Burgustinsky One' of 27 August 1991 No. 279P-IX. At: National Archive of the Republic of Kalmykia. Coll. P-1. Cat. 4. File 3014. Pp. 140-141. (In Russ.) 
Decree of the Supreme Soviet of the Kalmyk ASSR 'On Establishment of Krasnopartizansky Rural Soviet in Yashaltinsky District’ of 18 October 1990 No. 97-IX. At: National Archive of the Republic of Kalmykia. Coll. P-1. Cat. 4. File 2998. P. 89. (In Russ.)

Decree of the Supreme Soviet of the Kalmyk ASSR 'On Historical Renaming of Krasnoselsk back to Iki-Bukhus, and Krasnoselsky Rural Soviet of People’s Deputies (Maloderbetovsky District) to Iki-Bukhusovsky One' of 18 October 1990 No. 100-IX. At: National Archive of the Republic of Kalmykia. Coll. P-1. Cat. 4. File 2998. P. 92. (In Russ.)

Decree of the Supreme Soviet of the Kalmyk ASSR 'On Historical Renaming of Prudovy back to Naintakhn, and Prudovsky Rural Soviet of People's Deputies (Tselinny District) to Naintakhinsky One' of 18 October 1990 No. 98-IX. At: National Archive of the Republic of Kalmykia. Coll. P-1. Cat. 4. File 2998. P. 90. (In Russ.)

Decree of the Supreme Soviet of the Kalmyk ASSR 'On Historical Renaming of Polynnoe back to Bergin, and Polynensky Rural Soviet of People's Deputies (Yustinsky District) to Berginsky One' of 18 October 1990 No. 99-IX. At: National Archive of the Republic of Kalmykia. Coll. P-1. Cat. 4. File 2998. P. 91. (In Russ.)

Law of the Kalmyk ASSR 'On Amendments and Additions to the Constitution (Fundamental Law) of the Kalmyk ASSR' of 2 November 1989. Sovetskaya Kalmykiya. 1989, November 15. Pp. 1-2. (In Russ.)

Law of the Kalmyk ASSR 'On Amendments and Additions to the Constitution (Fundamental Law) of the Kalmyk Autonomous Soviet Socialist Republic' of 16 August 1990 No. 69-IX. At: National Archive of the Republic of Kalmykia. Coll. P-1. Cat. 4. File 2996. Pp. 17-18. (In Russ.)

Letter of Permanent Interdepartmental Commission for Geographical Names, Chief Directorate of Geodesy and Cartography, Council of Ministers of the USSR - to Soviets Affairs Department, Supreme Soviet of the Kalmyk SSR of 25 September 1991. At: National Archive of the Republic of Kalmykia. Coll. P-1. Cat. 4. File 2543. Pp. 13-15. (In Russ.)

Letter to Chairman of the RSFSR Supreme Soviet B. N. Yeltsin (No Date Mentioned, not until 15 November 1990). At: National Archive of the Republic of Kalmykia. Coll. P-1. Cat. 4. File 2541. Pp. 18-19. (In Russ.)

On Changes in the Administrative-Territorial Division of the RSFSR. Vedomosti Verkhovnogo Soveta RSFSR (RSFSR Supreme Soviet Gazette). 1962. No. 23 (June 14). 368 p. (In Russ.)

On Changes in the Administrative-Territorial Division of the RSFSR. Vedomosti Verkhovnogo Soveta RSFSR. 1963. No. 35 (September 5). 736 p. (In Russ.)

On Changes in the Administrative-Territorial Division of the RSFSR. Vedomosti Verkhovnogo Soveta RSFSR. 1965. No. 52 (December 30). 1228 p. (In Russ.)

On Changes in the Administrative-Territorial Division of the RSFSR. Vedomosti Verkhovnogo Soveta RSFSR. 1966. No. 28 (July 14). 592 p. (In Russ.)

On Changes in the Administrative-Territorial Division of the RSFSR. Vedomosti Verkhovnogo Soveta RSFSR. 1966. No. 41 (October 13). 904 p. (In Russ.)

On Changes in the Administrative-Territorial Division of the RSFSR. Vedomosti Verkhovnogo Soveta RSFSR. 1988. No. 3 (January 21). 56 p. (In Russ.)

Order of the Presidium of the Supreme Soviet of the Kalmyk ASSR - Khalmg Tangch 'On Establishment of Sarulsky Rural Soviet in Chernozemelsky District' of 27 August 1991 No. 281P-IX. At: National Archive of the Republic of Kalmykia. Coll. P-1. Cat. 4. File 3015. P. 49. (In Russ.)

\section{References}

Barsenkov A. S. Policy of perestroika and reform of Soviet society: 1985-1991. Rossiyskaya istoriya. 2014. No. 6. Pp. 77-98. (In Russ.) 


\section{История}

Chuchkalov A. S., Alekseev A. I. 'New' rural settlements - former urban-type settlements. Izvestiya Rossiyskoy akademii nauk. Seriya geograficheskaya. 2019. No. 6. Pp. 18-34. (In Russ.)

Deportation of the Kalmyk People: Memorial Book. Vol. 1. Book 3: Restoration of Autonomy and Rehabilitation of the Kalmyk People. Part 2: Rehabilitation of the Kalmyk People (1964-2003). Coll. Documents and Materials. Elista: Kalmyk Book Publ., 2004. 684 p. (In Russ.)

Dudarev V. A., Evseeva N. A. (comps.) The USSR. Administrative-Territorial Division of Union Republics: as of January 1, 1987. Reference Book. Presidium of the Supreme Soviet of the USSR. Moscow: Izvestiya, 1987. 670 p. (In Russ.)

Kichikova N. A., Mandzhieva E. B., Suprun V. I. Republic of Kalmykia: Toponymic Dictionary. Elista: Dzhangar, 2017. 272 p. (In Russ.)

Monraev M. U, Sangadzhiev P. D. Earliest history of Lagan and origins of its name revisited. In: Kalmyk ASSR. Studies in Historical Geography. Elista: Kalmyk Research Institute of History, Philology and Economics, 1981. Pp. 72-78. (In Russ.)

National Economy of the RSFSR: 1990. Statistical yearbook. Goskomstat RSFSR. Moscow: Republican Information and Publication Center, 1991. 592 p. (In Russ.)

Simagin Yu. A. Changes in roles of urban-type rural localities within Russia's settlement system throughout the $20^{\text {th }}$ century. Vestnik of Moscow City Teachers Training University: Natural Sciences. 2009. No. 1. Pp. 20-27. (In Russ.) 